\title{
Studerendes oplevelse af reorganisering af problembaseret læring på Aalborg Universitet
}

\author{
Bettina Dahl, lektor, Institut for Planlægning, Aalborg Universitet \\ Hans Hüttel, lektor, Institut for Datalogi, Aalborg Universitet \\ Reviewet artikel
}

\begin{abstract}
På Aalborg Universitet skete der i 2010 en omorganisering af studieordningerne på Det Teknisk-Naturvidenskabelige Fakultet. Blandt ændringerne var, at de traditionelle projekter fyldte mindre, en større adskillelse af den formelle sammenhæng mellem kurser og projekter og en opdeling af kurserne i blokke på 5 ECTS. Vi sammenlignede erfaringerne med både den nye og den gamle model hos 10.-semesterstuderende på tre uddannelser og konkluderede, at de adspurgte studerende lagde stor vægt på projektarbejdet både i den gamle og den nye model, men at der var en signifikant lavere oplevelse af sammenhæng på et semester nu ift. for. De studerende prioriterede nu kursuseksamen højere til sidst i semesteret. Overordnet viste undersøgelsen også, at forholdet mellem det fagorienterede og det problemorienterede i de to PBLmodeller, og PBL-modeller generelt, ofte ikke var som modellerne overordnet gav udtryk for. Eksempelvis havde den nye model flere fagorienterede kurser og var derfor fra én synsvinkel et skridt mod en mere fagorienteret PBL-model; pà den anden side havde de studerende i den nye model tidsmæssigt stadig mest fokus på det problemorienterede projekt og de fagorienterede kurser indeholdt PBL-lignende miniprojekter. De studerendes adfærd i en ændret undervisningsmodel var således mere kompleks, end man umiddelbart kunne antage.
\end{abstract}

\section{Problembaseret læring på AAU indtil 2010}

På Aalborg Universitet (AAU) har problembaseret læring (PBL) organiseret i projektarbejde været centralt siden universitetets start i 1974 (Barge, 2010). PBL er her karakteriseret ved, at de studerende arbejder i grupper med problemformulering, analyse og -løsning og arbejdsformen er styret af de studerende selv (de Graaff \& Kolmos, 2007). Problemerne er enten formuleret af de studerende eller ud fra et projektkatalog udarbejdet af vejlederne. De kan have forskellig karakter og behøver ikke at være "problemer" men kan også være en udforskning af noget ukendt. De studerende dokumenterer deres arbejde i en fælles projektrapport. Der er overordnet tre dimensioner i PBL på AAU (Kolmos et al., 2009): (i) Kognitiv dimension med 
problembaseret læring organiseret i projekter samt erfaringsbaseret læring; (ii) Kollabrativ dimension gennem studenterledte processer; (iii) Indholdsdimension som lægger vægt på fler- og tværfaglighed, eksemplaritet i valg af problemer og integration af teori og empiri.

PBL som princip anvendes på forskellige uddannelsestrin i Danmark og udlandet, og der findes forskellige opfattelser og modeller af PBL, også på universitetsniveau (Savin-Baden, 2007). PBL-universiteter reformerer med mellemrum deres PBLmodel. Neville og Norman (2007) beskriver for eksempel tre faser med store ændringer i studieordningerne på lægestudiet på McMaster University i Canada. Disse ændringer handler om forholdet mellem faglighed og kontekst. AAUs PBL-model kom af forskellige årsager under pres og blev markant ændret i 2010.

Indtil 2010 bestod et semester på Det Teknisk-Naturvidenskabelige Fakultet af aktiviteter på 30 ECTS fordelt på en projektenhed og et antal studieenhedskurser (SEkurser). En projektenhed var typisk normeret til 18 ECTS og bestod af projektarbejde og et eller flere projektenhedskurser (PE-kurser) med indhold direkte relateret til projektet. SE-kursernes indhold havde derimod ikke nødvendigvis forbindelse til projektenheden og var typisk traditionelle kurser struktureret som firetimers enheder med to timers forelæsning og to timers øvelser i grupper, hvor kursusholder og/eller hjælpelærere bistod grupperne. PE-kurser blev bedømt som del af projektenheden ved projekteksamen, mens SE-kurser blev bedømt ved separate eksaminer. Hvert semester havde en temabeskrivelse, der dækkede alle læringsmål, dvs. både projektenhed og SE-kurser (se Figur 1).

\begin{tabular}{|c|c|}
\hline PE-kurser & SE-kurser \\
\hline Projekt \\
\hline
\end{tabular}

Figur 1. Den gamle model for organisering af undervisningen på Det TekniskNaturvidenskabelige Fakultet på AAU.

\section{PBL-modellen efter 2010}

Der var flere grunde til at den tidligere model kom under pres og blev ændret. I 2007 blev det forbudt at afholde gruppeeksamen i hele landet og derfor blev gruppeeksamen af projekterne på AAU erstattet med en individuel projekteksamen. Vejlederne oplevede dog, at der til de individuelle eksamener blev brugt uforholdsmæssigt meget tid på at tjekke paratviden fra PE-kurserne på bekostning af selve projektet. Derfor ønskede man at adskille eksamen i projekt og kurser. Der skete også en harmonisering i forhold til dansk akkreditering af uddannelserne, og der foregik på samme tid en tilpasning omkring Bolognaprocessen og dermed en revision af studieordninger med hensyn til Ny karakterskala og formulering af læringsmål. Der var også en række indre faktorer så som, at der skulle gives større fleksibilitet for de studerende, samt at kurserne nu alle var af samme størrelse og skulle have pæda- 
gogisk mere varierende former. Det var også blevet udbredt at lade forskellige studieretninger følge samme kurser (samlæsning); og i en del tilfælde var samme kursus PE-kursus for nogle studerende men SE-kursus for andre på samme hold. Dette gjorde det sværere at målrette kurset mod projektarbejdet, og underviserne oplevede tydelig forskel i adfærd hos studerende alt efter om de skulle eksamineres særskilt i kurset eller ej. Den nye model blev kaldt 3*5+15-modellen, da hvert semester blev struktureret med 50\% til projektarbejdet (15 ECTS) og tre kursusmoduler á 5 ECTS hver (se Figur 2) (Kolmos \& Holgaard, 2012).

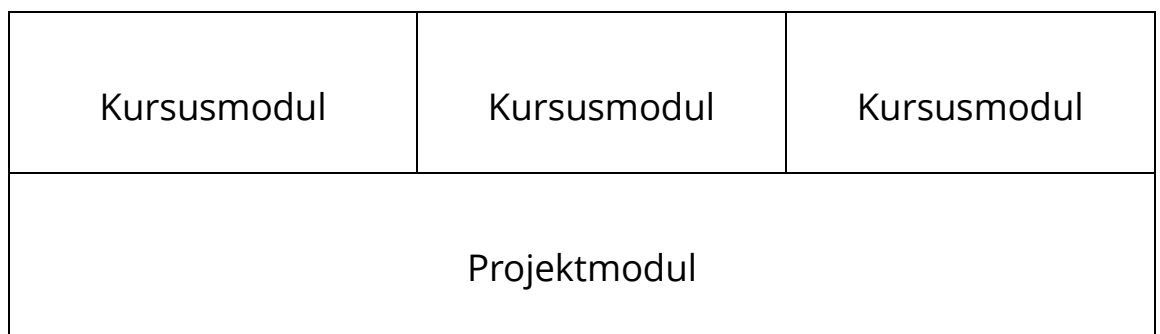

Figur 2. Den nye model for organisering af undervisningen på Det TekniskNaturvidenskabelige Fakultet på AAU.

I 3*5+15-modellen er der dog andre udfordringer. Der er ikke længere et eksplicit krav om, at projekt og kurser er relateret til hinanden - tværtimod er læringsmålene nu separate. Kolmos og Holgaard (2012:23) beskriver udfordringen sådan: "Principielt set kan ændringerne i den nye model betyde, at projektenhed og kursusenheder kan afvikles uafhængigt af hinanden. Som en af studienævnsformændene udtrykte det, så gør modellen alt, hvad den kan, for at signalere, at modulerne er adskilte, og det er så op til studienævnene at gøre alt, hvad de kan, for at bibeholde sammen-hæng." Det vil sige, der ønskes stadig sammenhæng på semestrene, selvom man formelt adskiller kurser og projekter.

En anden udfordring er, at projektet er normeret til lavere ECTS-belastning end før. Til gengæld er kurserne, der førhen ofte var 3 ECTS eller mindre, normeret til 5 ECTS. Fælles for begge modeller er dog, at starten af semestrene er forholdsmæssigt kursustunge. Kurserne er færdige godt halvvejs gennem semestrene, hvorefter grupperne får mere tid til projekterne. En central forskel på de to modeller er dog forholdet mellem fagorientering og problemorientering (Illeris, 2007:252-254), hvor kurserne udgør et fagorienteret element i begge modeller. De to PBL-modeller udtrykker hver deres syn på forholdet imellem fagorientering og problemorientering, og dette ses også i de forskellige evalueringsformer (læringsmålene i PE-kurserne blev undersøgt ved projekteksamen). En undersøgelse af ændringer i de studerendes adfærd i begge modeller vil give indsigt i, hvorledes forskellene i de to PBLopfattelser manifesterer sig.

\section{Vores forventning om ændringer}

Vi har undersøgt kandidatstuderende, der immatrikulerede i 2008, da den nye model gradvist blev faset ind således, at den gjaldt for førsteårsstuderende anno 2010, men først for alle andre studerende anno 2011. Førsteårsstuderende anno 2008 har således erfaret den gamle model i tre år på bachelordelen (sommer 2008-11) og den nye 
model i to år på kandidatdelen (sommer 2011-13). De har derfor typisk skrevet deres speciale i foråret 2013 og har således overblik over hele uddannelsen. Disse studerende har oplevet begge modeller gennem adskillige semestre, hvorfor det også kun var sådanne studerende, der reelt kunne give udtryk for, hvordan de ydre ændringer påvirkede deres adfærd. Vore forventninger til deres ændrede adfærd byggede på ovennævnte udfordringer (Kolmos \& Holgaard, 2012) og var derfor:

1. Undervisning: de studerende oplevede at kurserne blev mindre relevante for projektarbejdet, da der ikke længere var en formel sammenhæng på semestret mellem kurser og projekter, specielt var der ikke længere PE-kurser.

2. Bedømmelse: kursuseksamen oplevedes som værende af større vigtighed af de studerende, da der nu var flere ECTS til kurserne, som nu alle havde separate eksamener.

3. Adfærd i forhold til tidsforbrug og prioritering: de studerende vægtede indsatsen i projektet lavere end i kurser, da der nu var mindre ECTS til rådighed til projekterne end tidligere.

Artiklen rapporterer således de studerendes erfaringer med to PBL-modeller; det er ikke en bred undersøgelse af generelle aspekter af to PBL-modellers overordnede organisation og pædagogik. Det kan forekomme indlysende, at studerendes adfærd vil ændre sig i en ændret PBL-model, men præcis hvordan, denne ændrede adfærd manifesterer sig, er ikke nødvendigvis indlysende. At afdække, hvordan adfærden rent faktisk er ændret, er centralt i undersøgelsen.

\section{Metode}

\section{Struktur på undersøgelsen og fund af deltagere}

Vi valgte at fokusere på enkelte cases (uddannelser) og fik derfor via rundsending af e-mails fat i fire kandidatstuderende fra Datalogi og fire fra Arkitektur og Design, som tilhørte to forskellige skoler på Det Teknisk-Naturvidenskabelige Fakultet. Første trin i undersøgelsen var, at vi foretog to kvalitative fokusgruppeinterviews (Kvale, 1996) med disse studerende i vinteren 2013 for at få viden om, hvilke typer spørgsmål, det kunne være relevant at stille i spørgeskemaet rettet mod alle studerende på de pågældende studieretninger sommeren 2013. Til den kvantitative del valgte vi dog kandidatstuderende fra tre uddannelser: Arkitektur og Design, Datalogi samt Software. Softwareuddannelsen blev inkluderet for at få en større population af studerende fra samme skole som Datalogi. Uddannelserne Software og Datalogi havde stort fælles indhold, hvorfor vi kunne slå disse to grupper sammen og stadig opfatte dem som én population.

Da vi ønskede at undersøge den selvrapporterede adfærd hos studerende, der har oplevet begge modeller, opdelte vi spørgeskemaet i to dele: En før-del om de studerendes oplevelse af bachelorforløbet (gamle model), og en efter-del om deres oplevelse af kandidatforløbet (nye model). Inden for hver del af spørgeskemaet stillede vi 
stort set de samme spørgsmål. Enkelte omhandlede dog alene den ene model. Selvom de fleste af spørgsmålene derfor bogstaveligt var ens, har vi dog kun spurgt om omtrent det samme. Der var følgende grunde til, at vi ikke meningsfyldt kunne spørge om præcist det samme:

- $\quad$ Der var altid et spring i dybde/bredde-fokus fra bachelor til kandidat

- De studerende har opnået en modenhed undervejs, der kunne give sig udslag i en ændret opfattelse af det at være studerende på AAU

- $\quad$ Studieordningerne for kandidatuddannelserne var nye; dette var første "gennemløb"

Vi kunne måske have fået en mere ren sammenligning, hvis vi havde sammenlignet studerende, som kun havde prøvet den gamle model, med andre, som kun havde oplevet den nye model. Men for at kunne gøre dette, skulle vi sammenligne fx specialestuderende anno 2015 med ditto fra 2009, og dette ville give andre problemer med hensyn til de adspurgtes erindrede opfattelser. Årgangen af specialestuderende 2013 gav en unik mulighed for at udforske oplevelsen hos nuværende studerende, som i stor grad har erfaret begge modeller.

\section{Interviews og udvikling af spørgeskema}

Vi udførte to fokusgruppeinterview af hver en times varighed. Førstnævnte forfatter foretog begge interviews, det ene dog sammen med anden kollega. Interviewene var semistrukturerede med en liste af spørgsmål, vi ønskede besvaret. Vi brugte interviewene til at formulere de spørgsmål, som dannede baggrund for spørgeskemaet, men de blev ikke transskriberet (Kvale, 1996).

Spørgeskemaet blev udformet i Surveyxact og distribueret til 115 studerende. Vi modtog svar fra 29 (7 fra Datalogi, 11 fra Arkitektur og Design og 11 fra Software), dvs. en svarprocent på 25. Dette var lavere end ønsket, men desværre ikke usædvanligt for kursusevalueringer eller online-undersøgelser i det hele taget (Nulty, 2008).

\section{Statistiske analyser}

Vi undersøgte først, om der var signifikante forskelle på, hvordan de studerende i de to grupper (Arkitektur og Design sammenlignet med Datalogi og Software-gruppen) besvarede hvert enkelt spørgsmål. Til denne sammenligning benyttede vi en chi-ianden test ( $\chi 2$ ), hvor kategorierne 'helt enig' og 'overvejende enig' blev slået sammen og sammenlignet med kategorierne 'helt uenig' og 'overvejende uenig'. Der var kun signifikante forskelle (alfa $=5 \%$ ) i svarene på et enkelt spørgsmål, som alene omhandlede den gamle model. De studerende er derfor behandlet som én stor gruppe for alle de andre spørgsmåls vedkommende.

I sammenligningen af studerendes holdning til de to modeller kunne svarene ikke antages at være uafhængige, og vi kendte ikke fordelingen af populationen. Vi har derfor valgt den ikke-parametriske Wilcoxon Matched Pairs Rank test (2-tailed) til 
sammenligning af ordinale data i afhængige samples til sammenligning af de studerendes svar om de to PBL-modeller (Siegel, 1956).

\section{Analyse af spørgeskemaer}

Vi vil nu gennemgå resultaterne for de tre forventninger. Analysen er primært statistisk, men enkelte steder har vi inddraget udtalelser fra interviewene eller citeret fra de kommentarer, de studerende skrev i spørgeskemaet. I det nedenstående skriver vi "de studerende", hvormed vi mener de studerende i stikprøven.

\section{De studerendes oplevelse af undervisningen}

Da de studerende i undersøgelsen var på 10. semester mente vi, at de kunne vurdere, om det, de lærte i kurserne og projekterne, var vigtigt for deres uddannelse. I begge modeller blev projekterne bedømt signifikant mere vigtige for uddannelserne end kurserne (Gamle: $z=-2,61 ; p=0,009$; Nye: $z=-2,47 ; p=0,014$ ). Vi spurgte også, om kurserne var relevante for projektet på det pågældende semester. Svarene var generelt positive om begge PBL-modeller. Ca. halvdelen af de studerende (52\% gamle mod $46 \%$ nye; $z=1,25 ; p=0,211$ ) svarede enten helt enig eller overvejende enig, mens ca. en tredjedel (henholdsvis 32\% og 29\%) svarede neutral til dette spørgsmål. Vi spurgte også, om de studerende oplevede, at det de lærte i nogle af (PE)kurserne, ikke fandt anvendelse i projekterne (se Figur 3). Her så vi en signifikant forskel mellem modellerne $(z=-2,49 ; p=0,013)$, da $52 \%$ svarede enig om den gamle model, mens $88 \%$ svarede enig om den nye model.

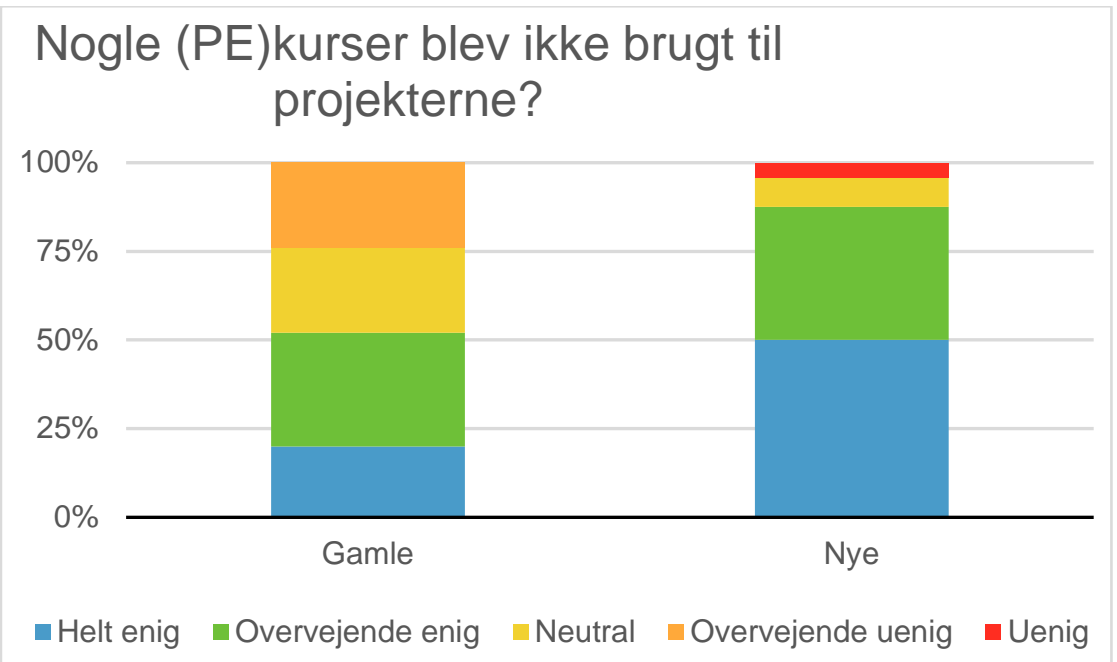

Figur 3. Spørgsmålet: Nogle kurser (PE) blev ikke brugt til projekterne?

På spørgsmålet, om de studerende oplevede en god sammenhæng på et semester mellem det, de skulle lære i kurserne, og det de skulle lære i projektet, var der igen en signifikant forskel $(z=2,21 ; p=0,027)$. For den gamle model var der $56 \%$ positive tilkendegivelser, mens det tilsvarende tal for den nye model var 33\%. Med andre ord synes de studerende at opleve mindre sammenhæng mellem kurserne og projekter $\mathrm{i}$ den nye model. 
Det tydede således på, at der i den gamle PBL-model var større sammenhæng mellem kurser og projekter end i den nye PBL-model. Dette var ikke overraskende, da begrebet projektenhed ikke findes i den nye model. Mere overraskende var det, at halvdelen var enig i, at nogle PE-kurser i den gamle model ikke blev brugt til projekterne. Det vil sige, at den gamle model ikke altid var tro mod sine egne principper. Under alle omstændigheder tydede resultatet på en større fragmentering af et semester i henholdsvis en projektdel og en kursusdel. Under interviewene udtalte nogle studerende, at det generelt var sværere at få overlap mellem kurser og projekter på overbygningen, da der var mere specialisering her, og ideen med PE-kurser (altså den gamle model) passede derfor bedst på bachelordelen. Forholdet mellem fag- og problemorientering kan altså siges at være påvirket af, hvilket niveau de studerende var på, hvor det problemorienterede tilsyneladende passede bedst på bachelordelen. Dette kom også til udtryk i nogle af kommentarerne, som de studerende skrev i selve spørgeskemaet:

"Da jeg først prøvede denne form [den nye model] senere var der ikke samme sammenhæng mellem kurser og projekt, fordi projekterne var meget mere specialiserede [på kandidatdelen] [...] Så det er ikke fordi denne sammenhæng ikke er muligt generelt set, blot at den naturligvis ikke han opnås på samme niveau på de senere semestre fordi projekterne er mere specifikke."

Her beskrev en studerende, at eftersom studiet blev mere specialiseret på kandidatdelen, blev det stadigt sværere at sikre sammenhæng mellem et kursus, som lå mere fast, og projekter, som bevægede sig stadigt dybere ind i en specialisering.

I tråd med ovenstående skrev en anden studerende følgende i kommentarerne:

"Derfor er det faktisk meget rart at projekteksamen handler om projektet og ikke andet. Kurserne skal nok støtte op om projektet, på fx DAT2 (hvor vi lavede compilere) støttede flere af kurserne fint op om projektet, selvom de ikke var PE-kurser alle sammen. Men på de senere semestre, fx DAT3 (altså 5. semester), arbejdede mange med noget meget specifikt, som kun var fjernt relateret til PE-kurset. Derfor giver PE-kursusbetegnelsen ikke meget mening."

Her så vi yderligere, at længere hen i uddannelsen (selv på bachelordelen) var kursernes anvendelighed for projekterne ikke styret af, om de var PE- eller SE-kurser, da specialiseringen af projekterne gjorde en sådan inddeling mere vanskelig. Derfor var det heller ikke relevant at inddrage kurserne i projektbedømmelsen.

\section{Bedømmelsen}

Med hensyn til bedømmelse af kurser under en projekteksamen, var der blandt andet følgende kommentarer fra en studerende i spørgeskemaet:

“Normalt blev vi nemlig aldrig spurgt direkte om ting fra PE-kurserne, hvilket gjorde at den skønne dag en censor eller vejleder besluttede at spørge lidt til et PE-kursus, så kunne man nemt falde på røven." 
Denne kommentar illustrerede, at vi også så, at 76\% af de studerende tilkendegav, at PE-kurserne som regel kun blev evalueret i det omfang, de var blevet brugt i projektet. Dette indikerede, at idealet i den gamle model om integrering af kurser og projekter i praksis ikke altid blev fulgt.

Vi undersøgte også, hvordan de studerende prioriterede projekteksamen over for kursuseksamenerne til slut i semesteret. På spørgsmålet om projekteksamen fik højeste prioritet svarede de studerende næsten enslydende om de to modeller (gamle: 63\% enig; nye: 58\% enig) mens der på spørgsmålet, om kursuseksamenerne fik højeste prioritet (se Figur 4), skete en næsten signifikant $(z=-1,85 ; p=0,064)$ ændring af svarene fra $36 \%$ enig (gamle) til $63 \%$ enig (nye).

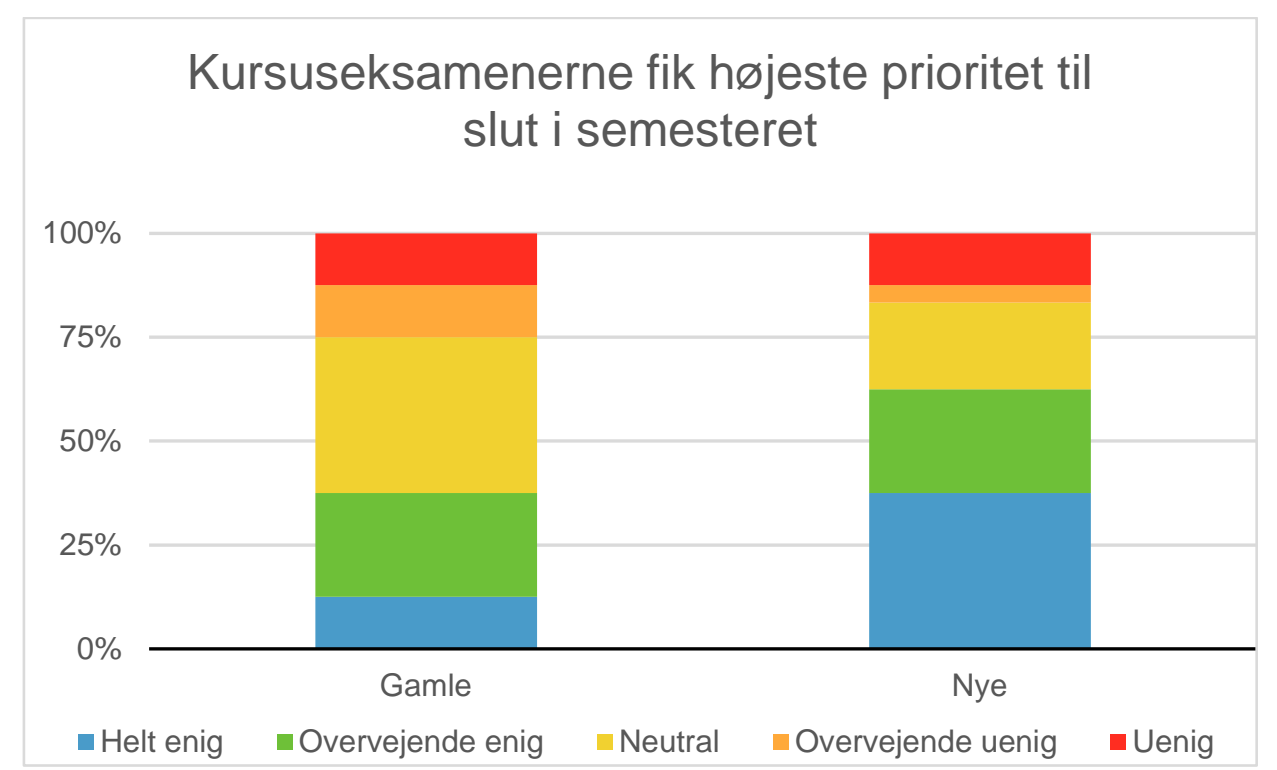

Figur 4. Spørgsmålet: Kursuseksamenerne fik højeste prioritet til slut i semesteret?

Efter reformen var $58 \%$ således enige i, at projekteksamen fik højeste prioritet til slut i semesteret, mens 63\% sagde det samme om kursuseksamenerne. Vi bemærkede, at summen er over $100 \%$ hvilket kunne tyde på, at for nogle studerende var begge meget vigtigere - men ingen har forrang over den anden eksamen. Kursuseksamenerne fik derfor i den nye model en lignende høj prioritet sidst på semesteret som projekterne. Her sås et element af lidt mere fagorientering i forhold til den gamle model.

\section{Adfærd med hensyn til tidsforbrug og prioritering}

Vi stillede også spørgsmål angående tidsforbruget på projekterne og kurserne. Ideelt set bør studerende bruge ca. lige meget tid samlet på de tre 5 ECTS kurser som projektet til 15 ECTS eftersom ECTS angav arbejdsbelastning for den gennemsnitlige studerende. I praksis ville de studerende dog "stemme med fødderne" og optimere deres tidsforbrug i forhold til oplevelse af relevans og udbytte enten i form af karakterer eller læringsmæssigt. På spørgsmålet, om de brugte mere tid på projektet end det antal ECTS de fik, svarede de i meget stor grad enig om begge modeller (henholdsvis $88 \%$ og $79 \%$ ). Med hensyn til tidsforbruget på kurserne var der signifikant forskel på modellerne ( $z=-3,5 ; p<0,001)$. Om den gamle model svarede $40 \%$, at de 
brugte mere tid end de fik ECTS-kredit for, mens hele $83 \%$ svarede tilsvarende for den nye model (se Figur 4). Studerende brugte med andre ord signifikant mere tid på kurserne i den nye model, end ECTS-tallet angav. Dette skyldtes sandsynligvis blandt andet en øget brug af miniprojekter. Miniprojekter var små obligatoriske PBLlignende opgaver fra kursusholder i et kursus, hvor studerende i grupper skulle anvende værktøjer eller teknologier på et konkret område. Ofte var et godkendt miniprojekt en betingelse for at kunne gå til eksamen. Disse blev indført i den nye model for dels at få mere PBL ind i kurserne, dels at sikre varierende undervisningsform i de kurser, der nu var større end i den gamle model. I den forbindelse skrev en af de studerende følgende om miniprojekterne i spørgeskemaet:

"I det hele taget følte jeg, at hele ideen med kurserne blev meget udvasket. Det virkede som om, vi lavede en masse kursusarbejde for kursusarbejdets skyld, og ikke fordi det skulle hjælpe os med vores egne projekter - eller læringsmålet for semestret. Specielt de til tider voldsomt omfattende "mini" projekter virkede ofte fuldstændigt formålsløse i det store billede, og det forstyrrede det projektarbejde, som vi ellers satte pris på."

I interviewene gav de studerende udtryk for, at de somme tider fordelte arbejdet med miniprojekterne mellem sig. De studerende fortalte også, at den store arbejdsbyrde med miniprojekterne ikke blot skyldtes overgangsproblemer med den nye model, da arbejdsbyrden ikke blev ret meget mindre senere.

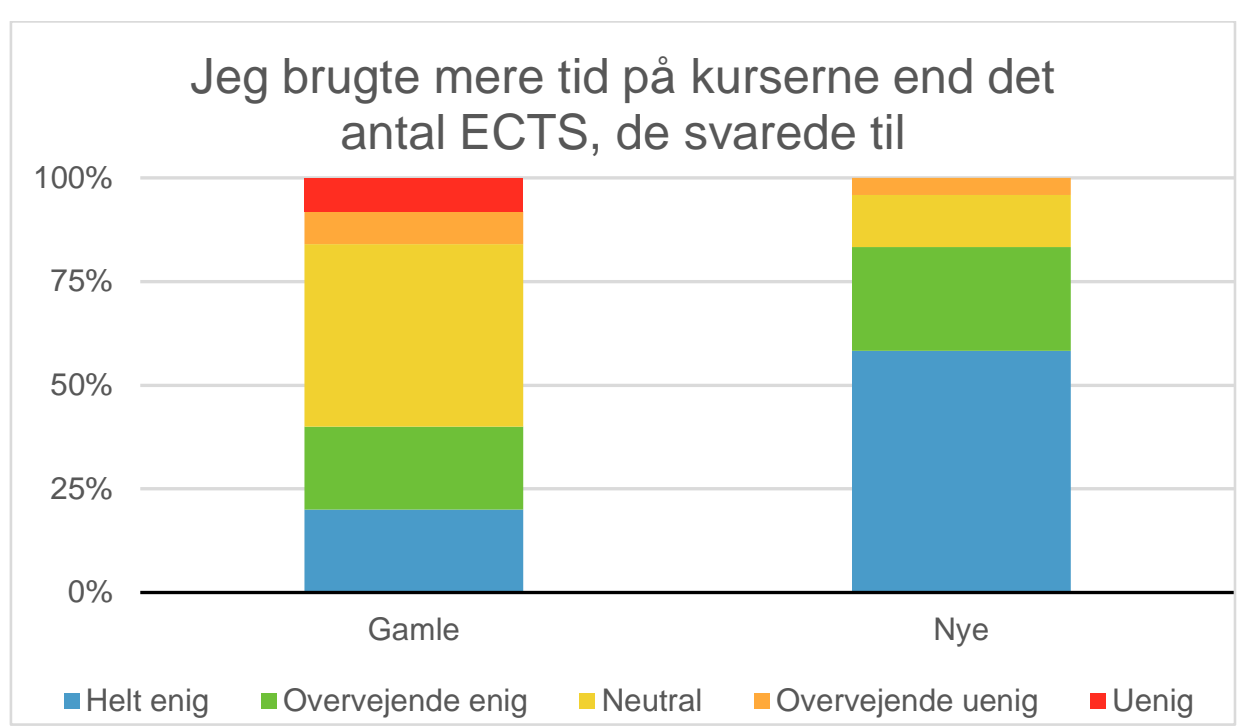

Figur 5. Spørgsmålet: Jeg brugte mere tid på kurserne end det antal moduler/ECTS, de svarede til?

Det var således tydeligt, at de studerende i begge modeller anså projekterne for at være mest centrale for deres uddannelse. Stort set alle adspurgte studerende brugte mere tid på projekterne, end de reelt fyldte i studieplanerne. Sammenligner vi, hvad der havde højeste prioritet gennem semesteret, ser vi endvidere, at projekterne havde signifikant højere prioritet end kurserne både i den gamle model $(z=4,19 ; p<$ $0,001)$ og i den nye $(z=2,85 ; p=0,002)$. 


\section{Diskussion}

Svarprocenten for den kvantitative undersøgelse er kun 25\%, hvilket sætter en begrænsning for, hvor sikker man kan være på, at svarene er repræsentative for alle studerende. Det forholdsmæssigt lave antal informanter betyder også, at risikoen for type 2 fejl er høj, altså at vi ikke er i stand til at observere en forskel, når der rent faktisk er en. I nedenstående vil vi ud fra analysen konkludere på, hvordan de, der trods alt har svaret, har tilkendegivet.

Hvad angår vor forventning om undervisning, var det tydeligt, at de studerende lagde stor vægt på projektarbejdet i begge modeller. De mente, at det er vigtigt med en god sammenhæng mellem kurser og projekt, men der var en signifikant forskel i den faktiske oplevelse heraf - i den nye model oplevedes sammenhængen som lavere (33\% nye mod 56\% gamle). Et eksempel derpå kunne være, at $44 \%$ af de studerende tilkendegav om den gamle model, at der i kurserne somme tider blev ændret på rækkefølgen af emnerne for at tilgodese projektet, mod kun $17 \%$ i den nye model. Dette modsagde ikke vor forventning, men resultatet tydede på, at de studerende i den nye model oplevede en lavere grad af sammenhæng og relevans.

Det var interessant i forhold til den anden forventning om prioritering af eksamen, at de studerende i den nye model prioriterede kursuseksamen lidt højere til sidst i semesteret sammenlignet med den gamle model og også lidt højere end projekteksamen i den nye model. Den ændrede adfærd kunne skyldes, at de studerende i den nye model fik et mere atomiseret syn på deres uddannelse. Omvendt fyldte kursusdelen flere ECTS end før, hvilke også kunne spille ind. Forskellen kunne også skyldes, at eksamen i PE-kurserne i den gamle model i nogle tilfælde havde "forstyrret" eksamen i projektet, hvis eksamen indeholdt elementer fra PE-kurserne, som ikke indgik i projektet. Det vil sige, der var her tale om en fagorientering i en ellers problemorienteret model.

Med hensyn til den tredje forventning om tidsforbrug og prioritering svarede de 29 studerende, at de i begge modeller brugte mere tid på projektet end det antal ECTS de fik. Men angående kurserne var der signifikant forskel. I den gamle model svarede 40\%, at de brugte mere tid end normeret på kurserne, mens det var hele $83 \%$ der gjorde det i den nye model. En af årsagerne kunne være miniprojekterne, som kom ind i den nye model. Miniprojekter var typisk et forsøg på at problembasere kursusmodulerne og på at betone større sammenhænge inden for et kursus, men det var tydeligt, at man herved skabte en forventning om et højere aktivitetsniveau svarende til det aktivitetsniveau, der var sædvanligt for de "egentlige" projekter.

Ovenfor nævnte vi tre grunde til, hvorfor vi i praksis ikke kunne spørge om præcist det samme i den gamle og den nye model. En af disse var, at specialestuderende anno 2013 var første "gennemløb" af den nye studieordning, hvorfor det kunne forventes, at der skulle ske justeringer. Dog beskrev de studerende, specielt i forhold til miniprojekternes arbejdsbelastning, at der ikke skete nogen forandring på de senere semestre. En anden grund til, at vi ikke mente at kunne spørge om præcist det sam- 
me, var den naturlige forskel i dybde-bredde mellem bachelor- og kandidatniveau. Det blev også klart i vores resultater, at denne forskel spillede ind, men ud fra undersøgelsens resultat var det allerede på sidste del af bachelordelen, at projekterne oplevedes så specialiserede, at skelnen mellem PE- og SE-kurser blev irrelevant. Med hensyn til de studerendes modenhed kunne vi ikke på baggrund af undersøgelsen sige noget præcist.

\section{Konklusion}

Overordnet kan vi konkludere, at de studerende i undersøgelsen ændrede adfærd som følge af en ændret PBL-model, og at denne ændrede adfærd i stor grad var, som det kunne forventes, qua vore forventninger. Dog viste undersøgelsen også, at forholdet mellem det fagorienterede og det problemorienterede i de to AAU PBLmodeller, og PBL-modeller generelt ofte ikke var, som modellerne overordnet gav udtryk for. Eksempelvis var den nye model med en større grad af fagorienterede kurser set fra én synsvinkel et skridt mod en mere fagorienteret PBL-model; på den anden side havde de studerende i den nye model tidsmæssigt stadig mest fokus på det problemorienterede projekt, da projektet stadig udgjorde det, der har mest fokus gennem semesteret, og derudover udgjorde miniprojekterne i de fagorienterede kurser en problemorientering af det fagorienterede. I den gamle model var problemorienteringen heller ikke ren, da eksamen i separate dele af PE-kurser somme tider "forstyrrede" eksamen i det problemorienterede projekt.

Forholdet mellem fagorientering og problemorientering er således ikke noget, der umiddelbart kan afgøres ud fra et overblik over, hvordan en fagplan ser ud. Fag- og problemorientering er ikke et spørgsmål om enten-eller, men er, og bliver i praksis, viklet sammen på mange forskellige måder. Det er her nødvendigt med en undersøgelse af, hvordan de forskellige modeller i praksis forandrer de studerendes adfærd. I den forbindelse beskriver Alarcãro (2007) vigtigheden af at "monitorere" en forandringsproces, blandt andet af hvordan de studerende opfører sig, og om noget derfor bør justeres. Når andre uddannelsesinstitutioner vil implementere PBL eller revidere en eksisterende PBL-model, er det derfor vigtigt at være opmærksom på, hvordan forskellige PBL-modeller kan påvirke de studerendes oplevelse af PBL og dens bestanddele og deres adfærd (herunder læringsadfærd) inden for samme. Vor undersøgelse viser, at de studerendes adfærd i en ændret PBL-model er mere kompleks end, hvad man umiddelbart kunne antage.

Et andet interessant resultat af denne undersøgelse er, at de studerende tilsyneladende finder, at den gamle og problemorienterede PBL-model passer bedst til bachelordelen, mens den nye fagorienterede passer bedst til overbygningen. Dette er det "omvendte" af, hvad der ofte siges, hvor argumentet er, at man først skal opnå et fagligt fundament, før man kan anvende faget problemorienteret. Der er igen ikke tale om enten-eller, men den stigende specialisering af en uddannelse på overbygningen betyder, at det i praksis er sværere at få overlap mellem de fagorienterede kurser og de problemorienterede projekter. Det kan derfor også konkluderes, at hvis man på universitetsniveau ønsker at gøre brug af PBL, vil en one-size-fits-all model 
sandsynligvis ikke passe til alle niveauer og tilfælde. Det er således nødvendigt med fleksibilitet i udformningen af PBL-modellerne.

Bettina Dahl Søndergaard er lektor på Aalborg Centre for Problem Based Learning in Engineering, Science and Sustainability under the auspices of UNESCO, som er en del af Institut for Planlægning på det Teknisk-Naturvidenskabelige Fakultet på Aalborg Universitet. Hun er ph.d. i Matematikdidaktik (RUC), cand.scient. i Matematik med sidefag i Samfundsfag ( $A A U$ ) og M.Sc. i Educational Research Methodology (Oxford). Hun har tidligere arbejdet på Aarhus Universitet og i Norge og USA med bl.a. matematiklæreruddannelse og udvikling af nationale prøver i matematik. Hendes forskningsinteresser handler om evaluering og eksamener inkl. karakterskalaer, begrebsforståelse af matematik, matematik i ingeniøruddannelser, overgangsproblemer og særligt dygtige elever. Hun har tidligere siddet i DUT's redaktion.

Hans Hüttel er lektor på Aalborg Universitet ved Institut for Datalogi på det TekniskNaturvidenskabelige Fakultet. Han er ph.d. i Theory of Computation (Edinburgh) og cand.scient. i Datalogi og Matematik (AAU). Han var formand for den revisionsgruppe, som reviderede studieordningerne ved datalogi- og softwareuddannelserne i 2010-2011 og var semesterkoordinator ved første studieår, da de nye studieordninger blev indført. Inden for datalogi er hans forskningsinteresser matematiske modeller for beregnelighed og programkorrekthed, her specielt typesystemer; inden for uddannelsesområdet er de bl.a. nye metoder til kursusundervisning, herunder 'the flipped classroom'.

\section{Litteratur}

Alarcãro, I. (2007). Changing to problem-based learning: The role of institutional leadership and faculty development. In E. De Graaff \& A. Kolmos (red.) Management of Change: Implementation of Problem-Based and Project-Based Learning in Engineering. Rotterdam: Sense.

Barge, S. (2010). Principles of problem and project based learning: The Aalborg model. Aalborg: Aalborg University.

De Graaff, E. \& Kolmos, A. (2007). History of problem-based and project-based learning. In E. De Graaff \& A. Kolmos (red.) Management of Change: Implementation of Problem-Based and Project-Based Learning in Engineering. Rotterdam: Sense.

Illeris, K. (2007). Læring. Roskilde: Roskilde Universitetsforlag.

Kolmos, A., de Graaff, E. \& Du, X. (2009). Diversity of PBL - PBL learning principles and models. In X. Du, E. de Graaff \& A. Kolmos (red.), Research on PBL Practise on Engineering Education. Rotterdam: Sense.

Kolmos, A. \& Holgaard, J. E. (2012). Evaluering af ændringerne i PBL modellen på TEKNAT AAU. Aalborg: UCPBL UNESCO Chair in Problem Based Learning.

Kvale, S. (1996). InterViews: An Introduction to Qualitative Research Interviewing. London: Sage.

Neville, A. J. \& Norman, G. R. (2007). PBL in the undergraduate MD program at McMaster University: Three iterations in three decades. Academic Medicine, 82(4), s. 370-374. 
Nulty, D. D. (2008). The adequacy of response rates to online and paper surveys: What can be done? Assessment \& Evaluation in Higher Education, 33(3), s. 301314.

Savin-Baden, M. (2007). Challenging models and perspectives of problem-based learning. In E. De Graaff \& A. Kolmos (red.) Management of Change: Implementation of Problem-Based and Project-Based Learning in Engineering. Rotterdam: Sense.

Siegel, S. (1956). Nonparametric Statistics: For the Behavioral Sciences. New York: McGraw-Hill. 